\title{
MICROEARTHQUAKE SOURCE LOCATIONS AND MECHANISMS: ICE STREAM B, WEST ANTARCTICA
}

\author{
(Abstract) \\ by \\ S. Anandakrishnan, D.D. Blankenship and C.R. Bentley \\ (University of Wisconsin-Madison, Geophysical and Polar Research Center, \\ 1215 W. Dayton Street, Madison, WI 53706-1692, U.S.A.)
}

\section{ABSTRACT}

An array of nine seismographic stations, each sensitive to all three components of motion, was deployed on Ice Stream B, West Antarctica, during the austral summer of 1985-86. The network was sensitive to high-frequency $(\approx 400 \mathrm{~Hz})$ seismic activity within a $350 \mathrm{~km}^{2}$ area of the ice stream, and the deployment geometry allows the precise determination of depths for events beneath the $10 \mathrm{~km}^{2}$ array. Microearthquakes from both beneath and beside the ice stream were detected and recorded (Blankenship and others 1987). Inversion of $\mathrm{P}$-wave and $\mathrm{S}$-wave travel times and radiation patterns allows the determination of locations and fault-plane solutions for many of these events.

We find that bottom events involve low-angle thrusting, in the down-stream direction, of ice or till; displacement is $\sim \frac{1}{2} \mathrm{~cm}$ per event over a $(15 \mathrm{~m})^{2}$ area. Such faulting is rare and releases an insignificant part of the total energy dissipated by ice flow. However, this is a possible mechanism for plucking of the ice-stream bed.

Fault-plane solutions for most major surface events are consistent with the opening of tensional fractures oriented transverse to ice flow. Precise location of these events shows that they correspond to open crevasses, mapped by Vornberger and Whillans (1986), that are oriented transverse to ice flow.
In addition, shear-wave splitting observed on some of the microearthquakes shows that the $c$-axes in the ice stream are slightly, but not strongly, anisotropic. Precise location of the sources requires the use of a detailed velocity-depth profile in the firn, which was obtained by seismic short-refraction studies (Anandakrishnan and others 1988 , this volume). A density-depth profile calculated from these velocities agrees well with direct density measurements on a single core nearby (Alley and Bentley 1988, this volume).

\section{REFERENCES}

Alley, R.B., and C.R. Bentley. 1988. Ice-core analysis on the Siple Coast of West Antarctica. Ann. Glaciol., 11, 1-7. Anandakrishnan, S., D.D. Blankenship, R.B. Alley, and C.R. Bentley. 1988. Density-depth profile determined by seismic-refraction studies: Ice Stream B, West Antarctica. Ann. Glaciol., 11, 198.

Blankenship, D.D., S. Anandakrishnan, J.L. Kempf, and C.R. Bentley. 1987. Microearthquakes under and alongside ice stream B, Antarctica, detected by a new passive seismic array. Ann. Glaciol., 9, 30-34

Vornberger, P.L., and I.M. Whillans. 1986. Surface features of Ice Stream B, Marie Byrd Land, West Antarctica. Ann. Glaciol., 8, 168-170

\section{SEISMIC MEASUREMENT OF THE GROSS CRYSTALLINE STRUCTURE OF A WEST ANTARCTIC ICE STREAM}

\author{
(Abstract) \\ by \\ D.D. Blankenship and C.R. Bentley \\ (University of Wisconsin-Madison, Geophysical and Polar Research Center, \\ 1215 W. Dayton Street, Madison, WI 53706-1692, U.S.A.)
}

\section{ABSTRACT}

Both in the interior of West Antarctica and on Ross Ice Shelf the ice column is dominated by ice with a distinct preferred $c$-axis orientation. An understanding of the dynamics of the West Antarctic ice sheet requires that we know the gross crystalline structure that characterizes each of its glaciological regimes (i.e. ice sheet, ice stream, and ice shelf). An important question is whether the strong fabric of the interior ice is preserved when this ice passes through the zone in which it is accelerated from sheet flow to stream flow, a zone that must be marked by strong longitudinal extension. Using generalized inverse techniques we have inverted seismic-reflection travel times observed at Upstream B camp (on Ice Stream B) to obtain the gross crystalline structure of the ice column at that location. We find that the strong fabrics of the interior are indeed destroyed; only a slight preferred orientation remains. The evidence at Upstream B camp is particularly strong because shear waves of both polarizations, which are particularly sensitive indicators of anisotropy, were analyzed as well as P-waves. 